\title{
User Acceptance of the E-Government Services in Malaysia: Structural Equation Modelling Approach
}

\author{
Norazah Mohd Suki \\ Universiti Malaysia Sabah, \\ Labuan, Malaysia
}

azahsuki@yahoo.com

\author{
T. Ramayah \\ Universiti Sains Malaysia, \\ Penang, Malaysia
}

ramayah@gmail.com

\begin{abstract}
This paper identifies the factors that determine users' acceptance of e-Government services and its causal relationships using a theoretical model based on the Technology Acceptance Model. Data relating to the constructs were collected from 200 respondents in Malaysia and subjected to Structural Equation Modeling analysis. The proposed model fits the data well. Results indicate that the important determinants of user acceptance of the e-Government services are perceived usefulness, ease of use, compatibility, interpersonal influence, external influence, self efficacy, facilitating conditions, attitude, subjective norms, perceived behavioral control, and intention to use e-Government services/system. Finally, implications and recommendations of these finding are discussed.
\end{abstract}

Keywords: e-Government, Usefulness, Ease of Use, Attitude, Intention to Use, Technology Acceptance Model

\section{Introduction}

Brown and Brudney (2001, p. 1) define Electronic Government (e-Government) as the use of technology, especially Web-based applications, to enhance access to and efficiently deliver government information and services. They categorize e-Government efforts into three broad categories of Government-to-Government (G2G), Government-to-Citizen (G2C), and Government-toBusiness (G2B). One may include two additional categories in this list: Government-to-Civil Societal Organizations (G2CS) and Citizen-to-Citizen (C2C), if the interaction among citizens is related to the other three categories of e-Government. By virtue of being a new mode of operation, e-Government has the potential to change the way that a governing body interacts with citizens and businesses. The realization of e-Government affects everyone because the role of government is all-encompassing and very complex.

In 1997, the Malaysian Government launched the e-Government initiative, generally known as e-

Material published as part of this publication, either on-line or in print, is copyrighted by the Informing Science Institute. Permission to make digital or paper copy of part or all of these works for personal or classroom use is granted without fee provided that the copies are not made or distributed for profit or commercial advantage AND that copies 1) bear this notice in full and 2) give the full citation on the first page. It is permissible to abstract these works so long as credit is given. To copy in all other cases or to republish or to post on a server or to redistribute to lists requires specific permission and payment of a fee. Contact Publisher@InformingScience.org to request redistribution permission.
Government, to reinvent itself to lead the country into the Information Age. As far as Malaysia is concerned, the implementation of e-Government was initiated with the introduction of the Multimedia Super Corridor (MSC) in 1996. The implementation of e-Government in Malaysia heralds the beginning of a journey of reinventing the government by transforming the way it operates, modernizing and enhancing its service 
delivery. e-Government seeks to enhance the convenience, accessibility, and quality of interactions with the public and businesses at large. Simultaneously, it was expected to improve information flow and processes within the government, improve the speed and quality of policy development, and improve coordination and enforcement. This would enable the government to be more responsive to the needs of its citizens (The Multimedia Super Corridor, n.d.).

e-Government is one of the seven flagship applications introduced in MSC. Under the eGovernment flagship, seven main projects were identified to be the core of the e-Government applications. The e-Government projects are Electronic Procurement (eP), Project Monitoring System (PMS), Electronic Services Delivery (eServices), Human Resource Management Information System (HRMIS), Generic Office Environment (GOE), E-Syariah and Electronic Labour Exchange (ELX). Besides these seven main projects under e-Government flagships, several government agencies have taken initiatives to introduce online services for the public projects, aiming to increase the ease and efficiency of public service to the people. Among others were Public Services Portal (myGovernment), e-Tanah, e-Consent, e-Filing, e-Local Government (e-PBT), eKehakiman, Custom Information System (SMK), Pensions Online Workflow Environment (POWER), and Training Information System (e-SILA).

Previous research identified determinants of potential users' adoption of e-Government services in a developing country using an amended version of the Unified Theory of Acceptance and Use of Technology (UTAUT) model (AlAwadhi \& Morris, 2008). The research described in this paper extends those findings and identifies other factors that could exert an influence. In view of the fact that there is a dearth of empirical studies on determinants of user acceptance in relation to eGovernment services in Malaysia, and in order to understand where Malaysia is in terms of public organizational support for e-Government, it was decided that a preliminary exploratory investigation of this issue in more detail was worthwhile. Hence, this research represents an initial attempt to address user acceptance of e-Government services in Malaysia. This research provides useful insights into the motivations underlying the intentions to use e-Government services in developing countries such as Malaysia.

\section{Literature Review}

A number of studies have investigated the adoption of e-Government services using technology acceptance theories and models, such as the Theory of Reasoned Action (TRA) (Fishbein \& Ajzen, 1975), the Theory of Planned Behavior (TPB) (Ajzen, 1991), the Technology Acceptance Model (TAM) (Davis, 1989), the Diffusion of Innovation (DOI) (Rogers, 1995), and the Unified Theory of Acceptance and Use of Technology (UTAUT) (Venkatesh, Morris, Davis, \& Davis, 2003). These studies provide useful insights and implications for understanding an individual's intention of using e-Government services. They also have identified a number of factors that determine the adoption of e-Government services, such as usefulness, ease of use, perceived risk, trustworthiness, compatibility, external influence, Internet safety, interpersonal influence, relative advantage, image, and facilitating conditions (See for example Carter \& Belanger, 2003; Huang, D’Ambra, \& Bhalla, 2002; Hung, Chang, \& Yu; 2006).

\section{Theory of Technology Acceptance Model}

The Technology Acceptance Model (TAM) is an influential extension of Ajzen and Fishbein's (1980) Theory of Reasoned Action (TRA). It was introduced and developed by Fred Davis in 1986 (refer to Figure 1). TAM is a model derived from a theory that addresses the issue of how users come to accept and use specific technology. The model suggests that when users are presented with, for instance, a new software package, a number of variables influence their decisions about how and when they will use it. There are two specific variables, perceived usefulness and 
perceived ease of use, which are hypothesized to be fundamental determinants of user acceptance (Davis \& Arbor, 1989).

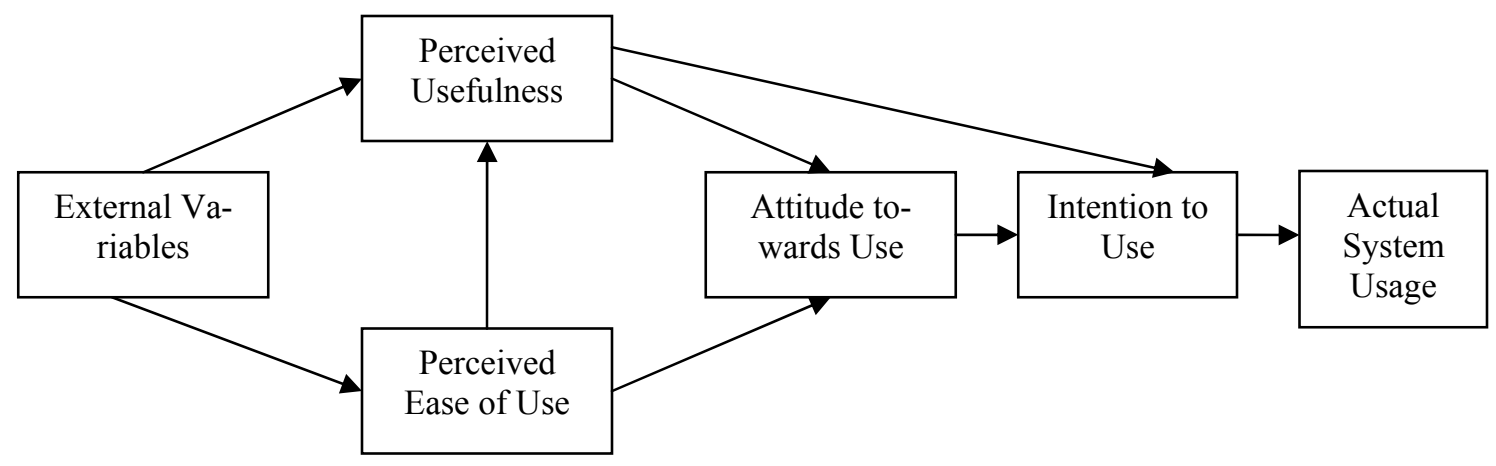

Figure 1: Technology acceptance model

TAM uses TRA as a theoretical basis for specifying the causal linkages between the two key features (perceived usefulness and perceived ease of use) and users' attitudes, intentions, and actual computer adoption behavior. TAM is considerably less general than TRA and is designed to apply only to computer usage behavior (Davis, 1989). But it can be readily extended to apply to any type of technology, and consequently it could be applied to the study of users' acceptance of eGovernment.

\section{Perceived Usefulness}

Perceived usefulness in the TAM model originally referred to job related productivity, performance, and effectiveness (Davis, 1989). This is an important belief identified as providing diagnostic insight into how user attitudes toward using (and intention to use) are influenced; perceived usefulness has a direct effect on intentions to use over and above its influence via attitude (Davis, 1989; Taylor \& Todd, 1995). Incorporating concepts used in Expectancy Theory, Triandis (1980) proposed that an important factor influencing behavior is the expected consequences of the behavior. Perceived usefulness was found to be significant constructs in the e-Government adoption literature (e.g. Carter \& Belanger, 2004, 2005). Past research was inconsistent on whether perceived usefulness was the stronger determinant. Fu, Farn, and Chao (2006) and Norazah, Ramayah, and Norbayah (2008) found that behavioral intention was largely driven by perceived usefulness. In regards to e-Government acceptance, we test the following hypothesis:

H1: Perceived usefulness will have a significant positive effect on Attitude towards eGovernment Services.

\section{Perceived Ease of Use}

Perceived ease of use is another major determinant of attitude toward use in the TAM model. This internal belief ties to an individual's assessment of the mental effort involved in using a system (Davis, 1989). Perceived usefulness and perceived ease of use are distinct but related constructs. Improvements in perceived ease of use may contribute to improved performance. Since improved performance defines perceived usefulness that is equivalent to near-term usefulness, perceived ease of use would have a direct, positive effect on perceived near-term usefulness. Davis (1989) once proposed to test the generality of the observed usefulness and ease of use tradeoff and to assess the impact of external interventions on these internal behavioral determinants. The empirical research findings are, however, mixed (Chau, 1996; Davis, 1989).

Perceived ease of use was found to be significant constructs in the e-Government adoption literature (e.g. Carter \& Belanger, 2004, 2005). Wang (2002) found that perceived ease of use was a 
stronger predictor of people's intention to e-file than perceived usefulness. Perceived ease of use was found to have positively influenced the behavioural intention to use a system (Fagan, Wooldridge, \& Neill, 2008; Hsu, Wang, \& Chiu, 2009; Ramayah, Chin, Norazah, \& Amlus, 2005). These results suggest the following hypothesis:

H2: Perceived ease of use will have a significant positive effect on Attitude towards eGovernment Services.

\section{Compatibility}

Compatibility is another important dimension of the innovation diffusion theory. In Tornatzky and Klein's (1982) meta-analysis of innovation, they found that an innovation was more likely to be adopted when it was compatible with the individual's job responsibilities and value system. Agarwal and Prasad (1999) found that the degree to which potential adopters are prepared to accept an Information Technology is affected by the way they are accustomed to work. Compatibility was found to be a significant determinant in citizen's intention to use an e-Government service (Carter \& Belanger, 2005; Hung et al., 2006). The setup of the e-Government services will be compatible with the way users work. Hence, we posit that:

H3: Compatibility will have a significant positive effect on Attitude towards eGovernment Services.

\section{Social Influences}

In Taylor and Todd's (1995) study, social influences were equated with subjective norms and defined as other people's opinions, the influence of superiors, and peer influence. Venkatesh and Davis (2000) later expanded social influences to include image as well as subjective norms. The notion of image is derived from the research on diffusion of innovations. Moore and Benbasat (1991) defined it as the extent to which use of an innovation is perceived as enhancing one's status in a social system. Davis and Arbor (1989) believed that in some cases people might use a system to comply with the mandates of others rather than their own feelings and beliefs. Empirical support for the relationship between social norms and behavior can be found in many studies (e.g. Tornatsky \& Klein, 1982; Venkatesh \& Davis, 2000). A critical consideration for eGovernment users (who usually perform in the public domain) is their sense of social image and other related factors such as speed of operation. Therefore, we posited that:

H4: External influence will have a significant positive effect on Subjective norms.

H5: Interpersonal influence will have a significant positive effect on Subjective norms.

\section{Self-efficacy}

Computer self-efficacy is defined as "an individual's perception of his or her own ability to use computer in the accomplishment of a task, rather than reflecting simple component skill" (Compeau \& Higgins, 1995). According to Bandura (1986), self efficacy is defined as the belief that one has about the capability to perform a particular behavior. Computer self efficacy can be operationalized at both the general computing behavior level and at the specific computer application level (Marakas, Yi, \& Johnson, 1998). The computer self efficacy construct is defined as "an individual's perception of efficacy in performing specific computer-related tasks within the domain of general computing" whereas application specific self-efficacy is defined as "an individual perception of self-efficacy in using a specific application or system within the domain of general computing" (Marakas et al., 1998).

Several studies have found that computer self-efficacy is positively related to perceived usefulness and perceived ease of use (Guriting \& Ndubisi, 2006; Wang, 2002). According to Hsu et al. 
(2009), there is a positive influence of computer self-efficacy on perceived usefulness and no significant influence on perceived ease of use. Individual's self-efficacy is a possible barrier to user acceptance of e-Government services. Individual's knowledge does influence e-Government services acceptance. Thus, it is hypothesized that:

H6: Self-efficacy will have a significant positive effect on Perceived Behavior Control.

\section{Facilitating Conditions}

Facilitating conditions was originally perceived as having two dimensions: resource factors (such as time and money needed) and technology factors regarding compatibility issues that may constrain usage. The argument was that when all other things are equal, behavioral intention and IT usage would be expected to be less likely as less time and money are available and as technical compatibility decreases (Taylor \& Todd, 1995). In the context of workplace technology use, facilitating conditions are now believed to include the availability of training and provision of support. This variable was tested in a number of technology acceptance studies, and empirical support was found for the proposed effect on perceived usefulness or perceived ease of use (Taylor \& Todd, 1995; Thompson, 2001; Venkatesh \& Davis, 2000).

From another perspective, Triandis (1980) viewed facilitating conditions as external controls related to the environment. Behavior cannot occur if objective conditions in the environment prevent it (Triandis, 1980) or if the facilitating conditions make the behavior difficult (Thompson, 2001). Policies, regulations, and legal environment are therefore all conditions critical to technology acceptance. These have been identified as the greatest limitations at present (Burnett, 2000). Standardization of protocols and other regulations will inevitably hasten the development of eGovernments around the world. Individual's facilitating resources are possible barriers to user acceptance of e-Government services. Thereby, we propose the following:

H7: Facilitating conditions will have a significant positive effect on Perceived Behaviour Control.

\section{Attitude}

Attitude has long been identified as a cause of intention. Psychologists have discussed the theoretical construct of attitude for decades. Attitude in Fishbein and Ajzen's (1975) paradigm is classified into two constructs: attitude toward the object and attitude toward the behavior. The latter refers to a person's evaluation of a specified behavior. This evaluation of a specified behavior leads to certain behavioral intention that further results in certain behavioral action. Adapting this general principle, attitude toward use in the TAM model is defined as the mediating affective response between usefulness and ease of use beliefs and intentions to use a target system. In other words, a prospective user's overall attitude toward using a given system is an antecedent to intentions to adopt (Davis, 1989). In user participation research, it is also believed that, prior to system development, users are likely to have vaguely formed beliefs and attitudes concerning the system to be developed (Hartwick \& Barki, 1994). For the same reason, in consumer research, attitude is the construct that receives most attention and is used most widely for predicting consumers' likelihood to adopt a new technology (Erevelles, 1998).

Pragmatically, consumers today have been exposed to a number of technology innovations. They are likely to have formed a favorable or unfavorable attitude about them irrespective of whether they have actually used the product in question. As an innovative system, e-Government is still in its infancy. Large numbers of users simply do not exist in many countries and regions. An investigation of attitudes toward using e-Government and identification of its relationship with intention to use is more appropriate and practically valuable for predicting usage behavior. Thus, it is hypothesized that: 
H8: Attitude will have a significant positive effect on Intention to Use e-Government Services.

\section{Subjective Norms}

The Subjective norm is a person's belief that most of the others who are important to him think he should (or should not) perform the behavior in question (Ajzen \& Fishbein, 1980). Subjective norms are internalization and identification. Internalization (Warshaw, 1980) can be explained thus: when a technology user perceives that an important person, such as the user's manager or father, thinks that the user should use this new technology, the user will incorporate that person's beliefs into his/her own belief structure. Internalization is equivalent to what Deutsch and Gerard (1995) refer to as informational (in contrast to normative) social influences, defined as influence to accept information from another as evidence about reality (cited in Venkatesh \& Davis, 2000).

Acceptance of ICT by managerial, professional, and operating level users is deemed a necessary condition for its success: however, resistance to computer systems from managers and professionals is a widespread problem (Attewell \& Rule, 1984; Davis \& Arbor, 1989; Igbaria \& Chakrabarti, 1990). Davis (1993) argues that lack of user acceptance has long been an impediment to the success of information systems which, if avoided, would improve performance on the job the goal of most organizationally based information systems. In accepting e-Government services, citizens tend to be affected by external and interpersonal influences. Social influence is an important determinant of behavior. The next hypothesis states therefore:

H9: Subjective norms will have a significant positive effect on Intention to Use eGovernment Services.

\section{Perceived Behavioral Control}

According to Ajzen (1991), perceived behavioral control reflects belief regarding access to the resources and opportunities needed to effect a behavior. Perceived behavioral control appears to encompass two components. The first is "facilitating conditions" (Triandis, 1980), which reflects the availability of resources needed to perform a particular behavior. This might include access to the time, money, and other specialized resources. In fact, as supporting technological infrastructures become easily and readily available, Internet commerce applications such as banking services will also become more feasible. Accordingly, the government can play an intervention and leadership role in the diffusion of innovation. The second component is self-efficacy (Ajzen, 1991), that is, being confident of the ability to behave successfully in the situation (Bandura, 1986). An individual with the self-assured skill to use a computer and the Internet is more inclined to adopt Internet banking. This component then refers to comfort with using the innovation. The acceptance of e-Government services is not entirely under citizens' control. Hence, we posit that:

H10: Perceived behavioral control will have a significant positive effect on Intention to Use e-Government Services.

All in all, the proposed research model is presented in Figure 2. 


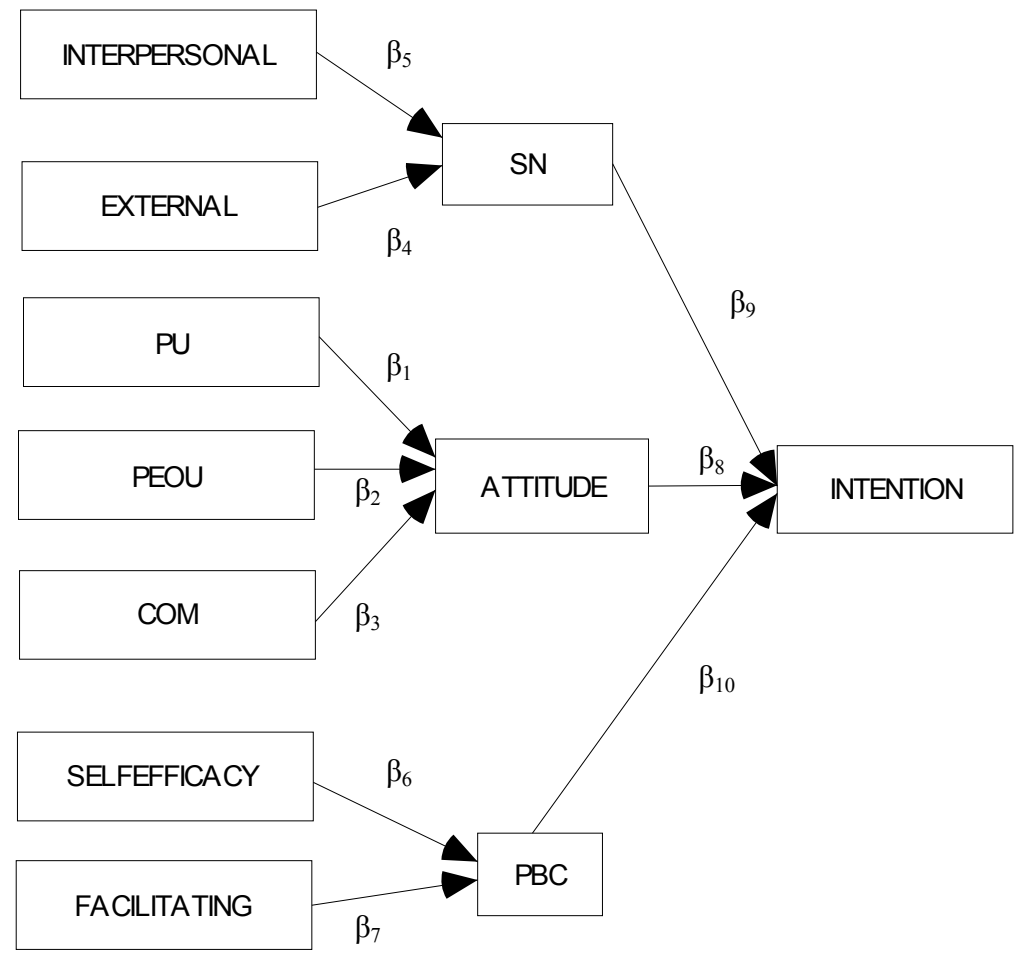

Figure 2: Research model

\section{Methodology}

Employees who work in Bayan Baru, Bayan Lepas, Sg. Dua, and Universiti Sains Malaysia staff, all located in Penang, Malaysia, were selected as the target sample using simple random sampling methods. 250 questionnaires were distributed and 200 respondents replied, i.e., the response rate was $80 \%$. More details about the instrument used are provided in Appendix A. The research model was tested using Structural Equation Modeling (SEM) techniques using AMOS 5.0 computer software. SEM is a comprehensive approach to testing hypotheses about relations among observed and latent variables (Hoyle, 1995). The statistical approach incorporates path analysis, factor analysis, and linear regression into a theoretical causal model for analysis of latent constructs and measurable variables, allowing simultaneous estimation of both measurement and structural sub-models (Anderson \& Gerbing, 1988).

\section{Findings and Discussions}

\section{Demographic Profile of Respondents}

The demographic profile of the surveyed respondents is presented in Table 1. The total sample for the survey consists of 200 respondents. The gender distribution of the survey respondents is $53.5 \%$ males and $46.5 \%$ females. The results also reveal that the respondents are predominantly aged between 30 and 55 years, which is $63.5 \%$ of the sample. More than $60 \%$ of the respondents are married. The majority of the respondents have been educated to college or higher education level: $41.5 \%$ are diploma holders, while $47 \%$ have Bachelor degrees or professional qualifications. In addition, $73.5 \%$ of the respondents used the Internet a few times a week; $35.5 \%$ of the 
respondents have dial-up connections at home; $52.5 \%$ of the respondents have broadband at work; and only $4.5 \%$ have no computer in their homes.

Table 1: Demographic profile of respondents

\begin{tabular}{|c|c|c|}
\hline & Frequency & Percentage \\
\hline \multicolumn{3}{|l|}{ Gender } \\
\hline Male & 107 & 53.5 \\
\hline Female & 93 & 46.5 \\
\hline \multicolumn{3}{|l|}{ Age } \\
\hline $18-29$ years old & 73 & 36.5 \\
\hline $30-55$ years old & 127 & 63.5 \\
\hline \multicolumn{3}{|l|}{ Marital status } \\
\hline Single & 66 & 33.0 \\
\hline Married & 134 & 67.0 \\
\hline \multicolumn{3}{|l|}{ Have any children } \\
\hline No & 70 & 35.0 \\
\hline Yes & 130 & 65.0 \\
\hline \multicolumn{3}{|l|}{ Race } \\
\hline Malay & 95 & 47.5 \\
\hline Chinese & 49 & 24.5 \\
\hline Indian & 56 & 28.0 \\
\hline \multicolumn{3}{|l|}{ Level of education } \\
\hline Secondary school & 21 & 10.5 \\
\hline Diploma & 83 & 41.5 \\
\hline Professional & 53 & 26.5 \\
\hline Bachelor degree & 41 & 20.5 \\
\hline Masters degree & 2 & 1.0 \\
\hline \multicolumn{3}{|l|}{ Sector of occupation } \\
\hline Government & 69 & 34.5 \\
\hline Non-government & 125 & 62.5 \\
\hline Not applicable & 6 & 3.0 \\
\hline \multicolumn{3}{|l|}{ Salary range } \\
\hline Not applicable & 6 & 3.0 \\
\hline$>$ RM 1000 & 20 & 10.0 \\
\hline RM 1000 to RM 2000 & 115 & 57.5 \\
\hline RM 2001 to RM 3000 & 52 & 26.0 \\
\hline RM 3001 to RM 4000 & 4 & 2.0 \\
\hline$<\mathrm{RM} 4000$ & 3 & 1.5 \\
\hline \multicolumn{3}{|l|}{ Internet usage } \\
\hline Never & 15 & 7.5 \\
\hline Less than per month & 10 & 5.0 \\
\hline Once a month & 10 & 5.0 \\
\hline Once a week & 18 & 9.0 \\
\hline Few times a week & 147 & 73.5 \\
\hline \multicolumn{3}{|l|}{ Network facilities at home } \\
\hline No computer & 39 & 19.5 \\
\hline Have / cannot connect to Internet & 44 & 22.0 \\
\hline Dial up & 71 & 35.5 \\
\hline Broadband & 46 & 23.0 \\
\hline \multicolumn{3}{|l|}{ Network facilities at work } \\
\hline No computer & 9 & 4.5 \\
\hline Have / cannot connect to Internet & 19 & 9.5 \\
\hline Dial up & 39 & 19.5 \\
\hline LAN & 28 & 14.0 \\
\hline Broadband & 105 & 52.5 \\
\hline
\end{tabular}

\section{Reliability Analysis}

Based on the Confirmatory Factor Analysis (CFA) results, we analyzed convergent validity, discriminant validity, and reliability of all the multiple-item scales, following the guidelines from 
previous literature (e.g., Fornell \& Larcker, 1981; Gefen \& Straub, 2005). The measurement properties are reported in Tables 2 and 3. Reliability was assessed in terms of composite reliability (CR), which measures the degree to which items are free from random error and therefore yield consistent results. Composite reliabilities in the measurement model ranged from 0.8783 to

\section{Table 2: Reliability and factor loadings}

\begin{tabular}{|c|c|c|c|}
\hline Constructs /Measurement Items & Standardized Loadings & $\mathbf{C R}$ & AVE \\
\hline Perceived Usefulness & & 0.960 & 0.822 \\
\hline use4 & 0.842 & & \\
\hline use1 & 0.979 & & \\
\hline use2 & 0.93 & & \\
\hline use 3 & 0.87 & & \\
\hline Perceived Ease of Use & & 0.892 & 0.776 \\
\hline ease3 & 0.679 & & \\
\hline ease2 & 0.603 & & \\
\hline ease 1 & 0.973 & & \\
\hline ease 4 & 0.849 & & \\
\hline Compatibility & & 0.952 & 0.933 \\
\hline com3 & 0.956 & & \\
\hline com2 & 0.919 & & \\
\hline com1 & 0.924 & & \\
\hline External Influence & & 0.873 & 0.821 \\
\hline exter3 & 0.784 & & \\
\hline exter2 & 0.773 & & \\
\hline exter1 & 0.905 & & \\
\hline Interpersonal Influence & & 0.865 & 0.84 \\
\hline peer3 & 0.786 & & \\
\hline peer2 & 0.903 & & \\
\hline peer1 & 0.831 & & \\
\hline Self-efficacy & & 0.920 & 0.889 \\
\hline self3 & 0.833 & & \\
\hline self2 & 0.915 & & \\
\hline self1 & 0.92 & & \\
\hline Facilitating Condition & & 0.672 & 0.648 \\
\hline facility 3 & 0.362 & & \\
\hline facility 2 & 0.779 & & \\
\hline facility 1 & 0.804 & & \\
\hline Attitude & & 0.829 & 0.668 \\
\hline attitude3 & 0.95 & & \\
\hline attitude 2 & 0.184 & & \\
\hline attitude1 & 0.754 & & \\
\hline attitude4 & 0.782 & & \\
\hline Perceived Behavioral Control & & 0.902 & 0.855 \\
\hline pbc3 & 0.926 & & \\
\hline pbc2 & 0.766 & & \\
\hline pbc1 & 0.874 & & \\
\hline Subjective Norm & & 0.896 & 0.847 \\
\hline norm3 & 0.811 & & \\
\hline norm2 & 0.856 & & \\
\hline norm1 & 0.874 & & \\
\hline Intention to Use & & 0.883 & 0.755 \\
\hline intention3 & 0.591 & & \\
\hline intention2 & 0.775 & & \\
\hline intention1 & 0.898 & & \\
\hline
\end{tabular}


0.9606 (see Table 2), above the recommended cutoff of 0.70 (Fornell \& Larcker, 1981; Nunnally $\&$ Bernstein, 1994) except for facilitating condition construct $(\mathrm{CR}=0.672)$, but its value is close to 0.70 .

Convergent validity was assessed in terms of factor loadings and average variance extracted (AVE). According to the prior study, convergent validity requires a factor loading greater than 0.50 and an AVE no less than 0.50. Facility 3 loading $=0.352$ is retained as it is one of the important statements related to facilitating condition. As shown in Table 2, all items had significant factor loadings higher than 0.50 . To evaluate discriminant validity, the AVE is used. All constructs have an AVE of at least 0.5 (Fornell \& Larcker, 1981) and all the square roots of each AVE value are higher than the off-diagonal correlation elements (Fornell \& Larcker, 1981).

Table 3: Correlation matrix and roots of the AVEs (shown as diagonal elements)

\begin{tabular}{|c|c|c|c|c|c|c|c|c|c|c|c|}
\hline & 1 & 2 & 3 & 4 & 5 & 6 & 7 & 8 & 9 & 10 & 11 \\
\hline (1) EXTERNAL & .906 & & & & & & & & & & \\
\hline (2) PU & .423 & .907 & & & & & & & & & \\
\hline (3)INTEERPERSONAL & .737 & .625 & .917 & & & & & & & & \\
\hline (4) $\mathrm{COM}$ & .660 & .718 & .757 & .966 & & & & & & & \\
\hline (5) SELF EFFICACY & .610 & .626 & .689 & .750 & .943 & & & & & & \\
\hline (6) FACILIATING & .475 & .635 & .538 & .695 & .768 & .805 & & & & & \\
\hline (7) $\mathrm{PEOU}$ & .416 & .533 & .522 & .644 & .743 & .595 & .881 & & & & \\
\hline (8) $\mathrm{PBC}$ & -.550 & -.620 & -.681 & -.788 & -.832 & -.765 & -.673 & .925 & & & \\
\hline (9) ATTITUDE & .579 & .505 & .532 & .634 & .541 & .508 & .319 & -.555 & .817 & & \\
\hline (10) $\mathrm{SN}$ & .658 & .658 & .800 & .777 & .711 & .640 & .518 & -.770 & .663 & .920 & \\
\hline (11) INTENTION & .540 & .450 & .557 & .551 & .464 & .470 & .181 & -.533 & .684 & .747 & .869 \\
\hline
\end{tabular}

\section{The Structural Model}

SEM is a model analysis technique encompassing methods such as covariance structure analysis, latent variable analysis, confirmatory factor analysis, path analysis, and linear structural relation analysis (Hair, Black, Babin, Anderson \& Tatham, 2006). SEM is also particularly useful in this paper because it can estimate "a series of separate, but interdependent, multiple regression equations simultaneously" in a specified structural model (Hair et al., 2006). Therefore, SEM is the most suitable analysis to estimate the strength of casual relationship of these constructs. Bagozzi and Yi (1988) suggested a set of fit indices used to examine the structural model (refer to Table 4).

Table 4: Results of the best fitting model

\begin{tabular}{lcc}
\hline Fit Indices & Benchmark & Value \\
\hline Absolute fit measures & & \\
CMIN $\left(\chi^{2}\right)$ & & 36.411 \\
DF & 3 & 26 \\
CMIN $\left(\chi^{2}\right) /$ DF & 0.9 & 1.400 \\
GFI (Goodness of Fit Index) & 0.08 & .968 \\
RMSEA (Root Mean Square Error of Ap- & & .045 \\
proximation) & & \\
Incremental fit measures & 0.80 & \\
AGFI (Adjusted Goodness of Fit Index) & 0.90 & .919 \\
NFI (Normed Fit Index) & 0.90 & .982 \\
CFI (Comparative Fit Index) & 0.90 & .995 \\
IFI (Incremental Fit Index) & 0.90 & .995 \\
RFI (Relative Fit Index) & & .962 \\
Parsimony fit measures & & \\
PCFI (Parsimony Comparative of Fit Index) & 0.50 & .470 \\
PNFI (Parsimony Normed Fit Index) & 0.50 & .464 \\
\hline
\end{tabular}


The Comparative Fit Index (CFI), Goodness of Fit Index (GFI) (Hair et al., 2006), Normed Fit Index (NFI), and Root Mean Square Error of Approximation (RMSEA) (Steiger, 1990) were used to judge the model fit. The Comparative Fit Index is a recommended index of overall fit (Gerbing \& Anderson, 1993), Goodness of Fit Index measures the fitness of a model compared to another model (Hair et al., 2006), Normed Fit Index measures the proportion by which a model is improved in terms of fit compared to base model (Hair et al., 2006), and the last (RMSEA) provides information in terms of discrepancy per degree of freedom for a model (Steiger, 1990). As suggested in the literature (Bollen \& Curran, 2006; Joreskog \& Sorbom, 1996; Kline, 1998) model fit was assessed by several indices. The accepted thresholds for these indices $\chi^{2} / \mathrm{df}$ ratio should be less than 3; the values of GFI, NFI, CFI, and IFI should be greater than 0.9; and RMSEA is recommended to be up to 0.05 and acceptable up to 0.08 (Gefen \& Straub, 2005). As shown in Table 4 , all of the model-fit indices exceed the respective common acceptance levels suggested by previous research, demonstrating that the model exhibited a good fit with the data collected. Thus, we could proceed to examine the path coefficients of the structural model.

\section{Analysis of Paths}

The test of structural model was performed using SEM. The test of the structural model includes: (a) estimating the path coefficients, which indicate the strengths of the relationships between the dependent variables and independent variables, and (b) the R-square value, which represents the amount of variance explained by the independent variables. The path coefficients in the SEM model represent standardized regression coefficients. The structural model reflecting the assumed linear, causal relationships among the constructs was tested with the data collected from the validated measures. Figure 3 shows the results of analysis. The square multiple correlation for the

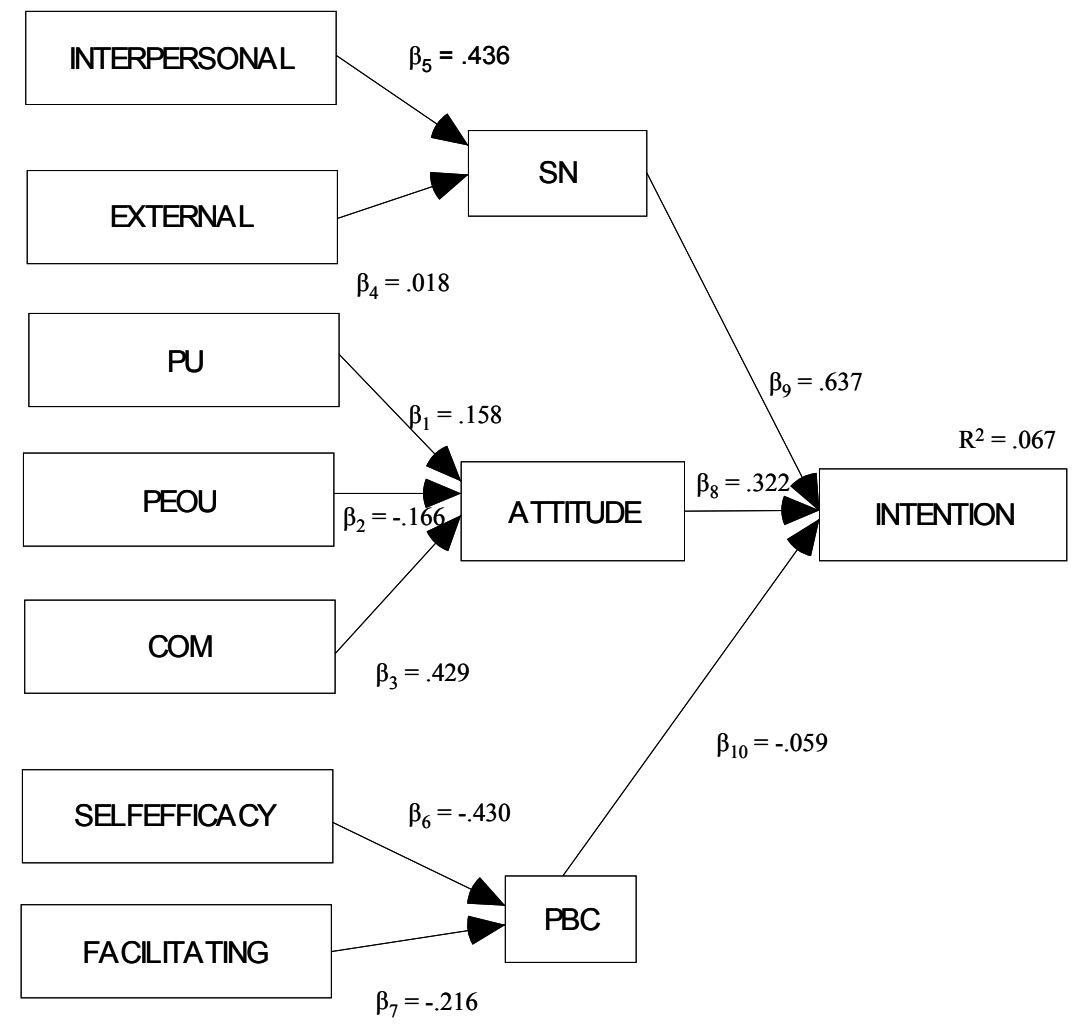

Figure 3: Estimated research model 
structural equations index indicates that $67 \%$ of the variation in the dependent variable is explained by the variation in the independent variables. Properties of the causal paths (standardized path coefficients $(\beta)$, standard error, $p$-value and hypotheses result) are shown in Table 5.

\section{Attitude}

The effect of Perceived Usefulness on Attitude was significant at 0.05 level $\left(\beta_{1}=0.158\right)$, as presented in Table 5 and Figure 3. Thus, H1 was supported. Using e-Government system would improve users' performance and productivity. To the users, the degree to which the e-Government system is perceived to be useful strongly influences their attitude. If the e-Government system is perceived to be useful, the users form positive attitudes and strong intentions towards using the system. They would find that the e-Government system is very useful as it would enhance their effectiveness. As expected, Perceived Ease of Use had a significant positive influence on Attitude $\left(\beta_{2}=-0.166\right)$. Thus, $\mathrm{H} 2$ was supported. Learning to use e-Government system would be easy for the users to use as they would find it easy to get better service via the system. Moreover, it would be easy for the users to become skillful at using e-Government system. Consistent with the theoretical expectation, Compatibility had a significant positive influence on Attitude $\left(\beta_{3}=0.429\right)$ at 0.05 level, suggesting support for H3. Using the e-Government system will fit well with the way users work and also fit into their work style. The setup of the e-Government system will be compatible with the way they work.

Table 5: Results of hypotheses tests

\begin{tabular}{lllcccc}
\hline \multicolumn{1}{c}{ Path } & & & $\boldsymbol{\beta}$ & S.E. & $\boldsymbol{p}$ & Result \\
\hline H1 ATTITUDE & $<---$ & PU & .158 & .064 & .033 & Supported \\
H2 ATTITUDE & $<---$ & PEOU & -.166 & .058 & .012 & Supported \\
H3 ATTITUDE & $<---$ & COM & .429 & .071 & .000 & Supported \\
H4 SN & $<---$ & EXTERNAL & .018 & .055 & .735 & Not Supported \\
H5 SN & $<---$ & INTERPERSONAL & .436 & .050 & .000 & Supported \\
H6 PBC & $<---$ & SELF EFFICACY & -.430 & .056 & .000 & Supported \\
H7 PBC & $<---$ & FACILITATING & -.216 & .051 & .000 & Supported \\
H8 INTENTION $<---$ & ATTITUDE & .322 & .051 & .000 & Supported \\
H9 INTENTION $<---$ & SN & .637 & .056 & .000 & Supported \\
H10 INTENTION $<---$ & PBC & -.059 & .053 & .391 & Not Supported \\
\hline
\end{tabular}

Notes: Path $=$ Relationship between independent variable on dependent variable; $\beta=$ Standardized regression coefficient; S.E. $=$ Standard error; $p=$ Level of significance

\section{Subjective Norms}

External Influence had insignificant influence on Subjective Norms at 0.05 level $\left(\beta_{4}=0.018\right)$, not supporting H4 (refer to Table 5 and Figure 3). External Influence has no significant positive effect on the relative importance of the Subjective Norms predictors. In contrast to our expectations, users that had privacy concerns were not more strongly affected by the TAM-related predictors than people with confidence in the e-Government services. The expectation was that users' with privacy concerns would be less likely to be influenced by external factors in accepting the system. Mass media reports have minimal influence on them to try out the e-Government services. Interpersonal influence had a significant positive influence on Subjective Norms at 0.05 level $\left(\beta_{5}=0.436\right)$, supporting H5. Users mainly noticed that influence from peers / colleagues / friend was strongly affected by the TAM-related predictors. They have the perception that they should use the e-Government services for quality delivery service. People they know think that 
using the e-Government services is a good idea and strongly influence them to try out the eGovernment system.

\section{Perceived Behavioral Control}

Table 5 and Figure 3 depict that it is worth noting that the effects of Self-efficacy on Perceived Behavioral Control was significant at 0.05 level $\left(\beta_{6}=-0.430\right)$ but the influence is negative. Hence, H6 was also supported. Users would feel comfortable using the e-Government system on their own. They would also be able to use the e-Government system even if there was no one around to help them. Likewise, the effect of Facilitating Condition on Perceived Behavioral Control was significant at 0.05 level with a negative influence $\left(\beta_{7}=-0.216\right)$. Thus, $\mathrm{H} 7$ was supported. Resources required to use the e-Government system is available to the users. They have access to hardware, software, and services needed to use the system. However, they are constrained by the lack of resources needed to use e-Government system.

\section{Intention to Use e-Government Services}

H8 was also supported as $p<0.05$. Attitude had a significant positive effect on Intention to use eGovernment services $\left(\beta_{8}=0.322\right)$. Encouragingly, users found that using the e-Government system would be a pleasant experience to them as it is a good idea. The second to last proposed hypothesis (H9) is about relationship between Subjective Norms on Intention to use e-Government services $\left(\beta_{9}=0.637 ; p<0.01\right)$. Subjective Norms was found to exert a significant positive effect on Intention to use e-Government services, supporting H9. Influence from peers/colleagues/friend offers great support to the users to use the e-Government system instead of any other alternative means.

The final hypothesis is about the relationship between Perceived Behavioral Control on Intention to use e-Government services. As shown in Table $5\left(\beta_{10}=-0.059 ; p=0.391\right)$, hypothesis $\mathrm{H} 10$ was not supported. In this respect, users are more likely not to be influenced by Perceived Behavioral Control. However, users with high intention to use e-Government rely stronger on the Perceived Behavioral Control; for them an increase in the level of Perceived Behavioral Control strongly increases future usage intentions on e-Government, seeing that using the e-Government system is entirely within their control. They would be able to use the e-Government system well because they have the resources, knowledge, and ability to use it successfully.

\section{Implications and Conclusion}

An empirical study was conducted to identify determinants of user acceptance for e-Government services in Malaysia. The results demonstrated that e-Government services acceptance can be explained in terms of perceived usefulness, perceived ease of use, compatibility, external influence, interpersonal/peers influence, self-efficacy, facilitating condition, and subjective norm. These findings confirm the results of AlAwadhi and Morris (2008, 2009), Carter and Belanger (2004, 2005), Dimitrova and Chen (2006), and Phang, Li, Sutanto and Kankanhalli (2005). Bhattacherjee (2000) indicated that user continuance intentions are determined by satisfaction with past use experience.

Managerial implications for government policy makers, government agencies, and system developers are also discussed. The findings can provide useful recommendation to development of practice and policy making, which are customer oriented and evidence based. In order to retain eGovernment service users' loyalty and retention, policy makers in their marketing strategies for eGovernment services should focus on these points: improving user interface of e-Government services, enhancing services security mechanisms, employing mass media marketing, and increasing the availability of necessary hardware and software for e-Government service use. Fur- 
thermore, for supporting and marketing e-Government service adoption, policy makers should emphasize the advertising of users' successful experience to attract non-users.

Next, to successfully implement e-Government services given constraints in resources, it is recommended that governmental agencies can set priorities based on the relative importance of the factors. To increase positive attitudes towards e-Government services, governmental agencies should develop implementation strategies that emphasize the usefulness of e-Government services, work style compatibility, and user trust. They should also seek to produce peer impact and external impact in outlining the marketing strategy in order to manipulate subjective norms. For example, encouraging e-Government service users to enhance their peer influence through various channels or endorsing e-Government service by well-known stars. In terms of reducing perceived behavioral control in using e-Government services, governmental agencies should focus on low self-efficacy users as they have lower perceived behavioral control than other users. Relatively, their perceived behavioral control has a weak suppressive effect on e-Government service adoption. Thus, immediate action to train and educate citizens is imperative in order to increase users' self-efficacy.

For system developers responsible for e-Government services design, it is worth taking note that perceived ease of use and compatibility are key factors influencing user acceptance of the eGovernment services. Therefore, system developers should provide a user-friendly interface, reinforce security mechanisms for e-Government services, and design a suitable information system flow more compatible with user's work style. Furthermore, to support e-Government service adoption, system developers could focus on developing effective user guidance, continuously improving security mechanisms, and using community of practice on Internet for promoting the eGovernment services and sharing use experience.

\section{Future Research}

Future studies should be based on more than the ten variables used here. This is because these ten variables cannot fully explain the factors influencing user acceptance of e-Government services. Consequently, future findings might be inconclusive. Future researchers should also increase the sample size and ensure that their respondents constitute a balanced demographic. A longitudinal approach could also be employed to study the factors that determine users' acceptance of eGovernment services.

\section{References}

Agarwal, R., \& Prasad, J. (1999). Are individual differences germane to the acceptance of new information technologies? Decision Sciences, 30(2), 361-391.

Ajzen, I. (1991).The theory of planned behavior. Organizational Behavior and Human Decision Process, $50,179-211$.

Ajzen, I., \& Fishbein, M. (1980). Understanding attitudes and predicting social behavior. Englewood Cliffs, NJ: Prentice-Hall .

AlAwadhi, S., \& Morris, A. (2008). The use of the UTAUT model in the adoption of e-government services in Kuwait. 41st Hawaii International Conference on System Sciences, Hawaii.

AlAwadhi, S., \& Morris, A. (2009). Factors influencing the adoption of e-government services. Journal of Software, 4(6), 584-590.

Anderson, J. C., \& Gerbing, D. W. (1988). Structural equation modeling in practice: A review and recommended two-step approach. Psychological Bulletin, 103(3), 411-423.

Attewell, P., \& Rule, J. (1984). Computing and organizations: What we know and we don't know. Communications of the ACM, 27(12), 1184-1192. 
Bagozzi, R. P., \& Yi, Y. (1988). On the evaluation of structural equation models. Academic of Marketing Science, 16, 74-94.

Bandura, A. (1986). Social foundations of thought and action: A social cognitive theory. New York, NY Macmillan Publishing Company.

Bhattacherjee, A. (2000). Acceptance of e-commerce services: The case of electronic brokerages. IEEE Transactions on Systems, Man, and Cybernetics: Part A. Systems and Humans, 30(4), 411-420.

Bollen, K. A., \& Curran, P. J. (2006). Latent curve models: A structural equation perspective. Wiley Series in Probability and Mathematical Statistics. New York, NY: Wiley.

Brown, M. M., \& Brudney, J. L. (2001). Achieving advanced electronic government services: An examination of obstacles and implications from an international perspective. Paper presented at the National Public Management Research Conference, Bloomington, IN, October.

Burnett, G. (2000). Information exchange in virtual communities: A typology. Information Research, 5(4). Available at http://information.net/ir/5-4/paper82.html

Carter, L., \& Belanger, F. (2003). Diffusion of innovation \& citizen adoption of e-government. The Fifth International Conference on Electronic Commerce (ICECR-5), Pittsburg, PA, 57-63.

Carter, L., \& Belanger, F. (2004). Citizen adoption of e-government initiatives. Retrieved May 21, 2010, from http://doi.ieeecomputersociety.org/10.1109/HICSS.2004.1265306

Carter, L., \& Belanger, F. (2005). The utilization of e-government services: Citizen trust, innovation and acceptance factors. Information Systems Journal, 15, 5-25.

Chau, P. Y. K. (1996). An empirical assessment of a modified technology acceptance model. Journal of Management Information Systems, 13(2), 185-204.

Compeau, D. R., \& Higgins, C. A. (1995). Computer self-efficacy: Development of a measure and initial test. MIS Quarterly, 19(2), 189-211.

Dimitrova, D. V., \& Chen, Y. C. (2006). Profiling the adopters of e-government information and services: The influence of psychological characteristics, civic mindedness, and information channels. Social Science Computer Review, 24(2), 172-188.

Davis, F. D. (1989). Perceived usefulness, perceived ease of use and user acceptance of information technology. MIS Quarterly, 13(3), 319-340.

Davis, F. D. (1993). User acceptance of information technology: System characteristics, user perceptions and behavioral impacts. International Journal of Man-Machine Studies, 38, 475-87.

Davis, F. D., \& Arbor, A. (1989). Perceived usefulness, perceived ease of use, and user acceptance of information technology. MIS Quarterly, September.

Deutsch, M., \& Gerard, H. (1995). A study of normative and informational social influences upon individual judgement. Journal of Abnormal and Social Psychology, 51, 624-36.

Erevelles, S. (1998). The role of affect of marketing. Journal of Business Research, 42(3), 199-215.

Fagan, M. H., Wooldridge, B. R., \& Neill, S. (2008). Exploring the intention to use computers: An empirical investigation of the role of intrinsic motivation, extrinsic motivation, and perceived ease of use. Journal of Computer Information Systems, 48, 31-37.

Fishbein, M., \& Ajzen, I. (1975). Belief, attitude, intention and behavior: An introduction to theory and research. Reading, MA: Addison-Wesley.

Fornell, C., \& Larcker, D. F. (1981). Evaluating structural equation models with unobservable and measurement error. Journal of Marketing Research, 18, 39-50.

Fu, J. R., Farn, C. K., \& Chao, W. P. (2006). Acceptance of electronic tax filing: A study of taxpayer intentions. Information \& Management, 43, 109-126. 
Gefen, D., \& Straub, D. W. (2005). A practical guide to factorial validity using PLS-graph: Tutorial and annotated example. Communications of the AIS, 16(5), 91-109.

Gerbing, D. W., \& Anderson, J. C. (1993). Monte Carlo evaluations of goodness-of-fit indices for structural equation models. In K. Bollen, \& J. S. Long (Eds.), Testing structural equation models. Newbury Park, CA: Sage.

Guriting, P., \& Ndubisi, N. O. (2006). Borneo online banking: Evaluating customer perceptions and behavioural intention. Management Research News, 29(1/2), 6-15.

Hair, J. F. Jr., Black, W. C., Babin, B. J., Anderson, R. E., \& Tatham, R. L. (2006). Multivariate data analysis (6th ed.). Upper Saddle, NJ: Pearson Prentice Hall.

Hartwick, J., \& Barki, H. (1994). Explaining the role of user participation in information systems use. Management Science, 40(4), 440-65.

Hoyle, R. H. (Ed.). (1995). Structural equation modeling. Thousand Oaks, CA: SAGE Publications. [This book provides a very readable, broken-down introduction to SEM. It discusses SEM in relation to AMOS software.]

Hsu, M. K., Wang, S. W., \& Chiu, K. K. (2009). Computer attitude, statistics anxiety and self-efficacy on statistical software adoption behavior: An empirical study of online MBA learners. Computers in $\mathrm{Hu}$ man Behavior, 25, 412-420.

Huang, W., D'Ambra, J., \& Bhalla, V. (2002). An empirical investigation of the adoption of e-government in Australian citizens: Some unexpected research findings. Journal of Computer Information Systems, 43(1), 15-22.

Hung, S. Y., Chang, C. M., \& Yu, T. J. (2006). Determinants of user acceptance of the e-government services: The case of online tax filing and payment system. Government Information Quarterly, 23, $97-$ 122.

Igbaria, M., \& Chakrabarti, A. (1990). Computer anxiety and attitudes towards microcomputer use. Behaviour \& Information Technology, 9(3), 229-241.

Joreskog, K. G., \& Sorbom, D. (1996). LISREL 8: User's reference guide. Chicago Scientific Software International.

Kline, R. B. (1998). Principles and practice of structural equation modeling. New York: Guilford.

Marakas, G., Yi, M., \& Johnson, R. (1998). The multilevel and multifaceted character of computer of computer self-efficacy: Toward clarification of the construct and an integrative framework for research. Information System, 9(2), 126-163.

Moore, G. C., \& Benbasat, I. (1991). Development of an instrument to measure the perception of adopting an information technology innovation. Information Systems Research, 2(3), 192-222.

The Multimedia Super Corridor. (n.d.). Kuala Lumpur: The Cooperate Communications Department, Multimedia Development Corporation Sdn. Bhd.

Norazah, M. S., Ramayah, T., \& Norbayah, M. S. (2008). Internet shopping acceptance: Examining the influence of intrinsic versus extrinsic motivations. Direct Marketing: An International Journal, 2(2), 97-110.

Nunnally, J. C., \& Bernstein, I. H. (1994). Psychometric theory (3rd ed.). New York: McGraw Hill.

Phang, C. W., Li, Y., Sutanto, J., \& Kankanhalli, A. (2005). Senior citizens adoption of e-government: In quest of the antecedents of perceived usefulness. 38th Hawaii International Conference on System Sciences.

Ramayah, T., Chin, Y. L., Norazah, M. S., \& Amlus, I. (2005). Determinants of intention to use an online bill payment system among MBA students. E-Business, 9, 80-91.

Rogers, E. (1995). Diffusion of innovations. New York: Free Press. 
Steiger, J. H. (1990). Structural model evaluation and modification: an interval estimation approach. Multivariate Behavioral Research, 25, 173-180.

Taylor, S., \& Todd, P. A. (1995). Understanding information technology usage: A test of competing models. Information Systems Research, 6(2), 144-176.

Thompson, S. H. T. (2001). Demographic and motivation variables associated with Internet usage activities. Internet Research: Electronic Networking Applications and Policy, 11(2), 125-137.

Tornatsky, L. G., \& Klein, K. J. (1982). Innovation characteristics and innovation adoptionimplementation: A meta-analysis of findings. IEEE Transactions on Engineering Management, EM29, February, 28-45.

Triandis, H. C. (1980). Values, attitudes and interpersonal behavior. Lincoln, NE: University of Nebraska Press.

Venkatesh, V., \& Davis, F. D. (2000). A theoretical extension of the technology acceptance model: Four longitudinal field studies. Management Science, 46(2), 186-204.

Venkatesh, V., Morris, M., Davis, G., \& Davis, F. (2003). User acceptance of information technology: Toward a unified view. MIS Quarterly, 27(3), 425-478.

Wang, Y. S. (2002). The adoption of electronic tax filing systems: An empirical study. Government Information Quarterly, 20, 333-352.

Warshaw, P. R. (1980). A new model for predicting behavioral intentions: An alternative to Fishbein. Journal of Marketing Research, 18, 153-72.

\section{Appendix A: Measuring instruments}

\begin{tabular}{|c|c|c|c|c|c|}
\hline $\begin{array}{l}\text { Usefulness } \\
\text { Using E- government system would improve my performance } \\
\text { Using E- government system would improve my productivity } \\
\text { Using E- government system would enhance my effectiveness } \\
\text { I would find E- government system useful }\end{array}$ & $\begin{array}{l}1 \\
1 \\
1 \\
1\end{array}$ & $\begin{array}{l}2 \\
2 \\
2 \\
2\end{array}$ & $\begin{array}{l}3 \\
3 \\
3 \\
3\end{array}$ & $\begin{array}{l}4 \\
4 \\
4 \\
4\end{array}$ & $\begin{array}{l}5 \\
5 \\
5 \\
5\end{array}$ \\
\hline $\begin{array}{l}\text { Ease-Of-Use } \\
\text { Learning to use E- government system would be easy for me } \\
\text { I would find it easy to get better service using E- government system } \\
\text { It would be easy for me to become skill full at using E- government sys- } \\
\text { tem } \\
\text { I would find E- government system easy to use }\end{array}$ & $\begin{array}{l}1 \\
1\end{array}$ & $\begin{array}{l}2 \\
2\end{array}$ & $\begin{array}{l}3 \\
3\end{array}$ & $\begin{array}{l}4 \\
4\end{array}$ & $\begin{array}{l}5 \\
5\end{array}$ \\
\hline $\begin{array}{l}\text { Compatibility } \\
\text { Using the E- government system will fit well with the way I work } \\
\text { Using the E- government system will fit into my work style } \\
\text { The setup of the E- government system will be compatible with the way } \\
\text { I work }\end{array}$ & $\begin{array}{l}1 \\
1 \\
1\end{array}$ & $\begin{array}{l}2 \\
2 \\
2\end{array}$ & $\begin{array}{l}3 \\
3 \\
3\end{array}$ & $\begin{array}{l}4 \\
4 \\
4\end{array}$ & $\begin{array}{l}5 \\
5 \\
5\end{array}$ \\
\hline $\begin{array}{l}\text { Peer influence } \\
\text { My peers/colleagues/ friend think that I should use the E- government } \\
\text { system } \\
\text { People I know think that using the E- government system is a good idea } \\
\text { People I know influence me to try out the E- government system }\end{array}$ & 1 & 2 & 3 & 4 & 5 \\
\hline $\begin{array}{l}\text { External influence } \\
\text { I read/ saw news reports that using E- government system was a good }\end{array}$ & 1 & 2 & 3 & 4 & 5 \\
\hline
\end{tabular}




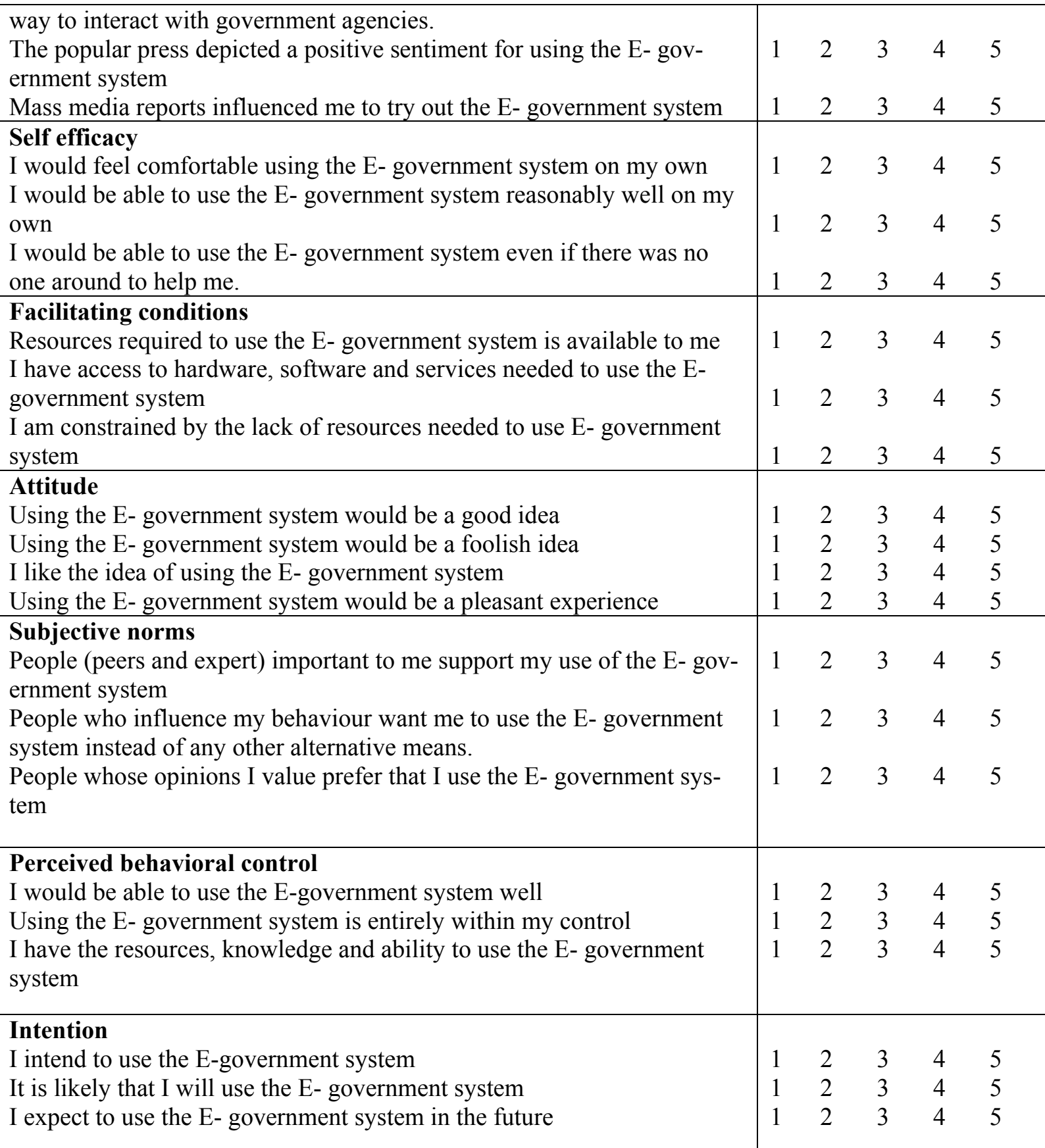




\section{Biographies}

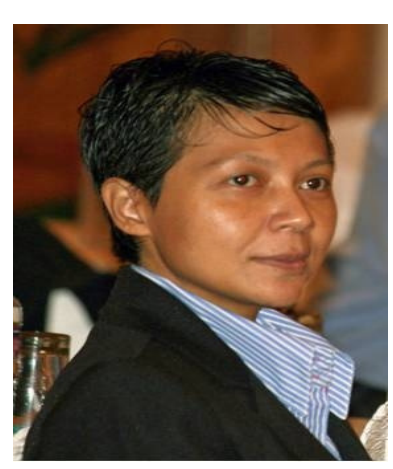

Assoc. Prof. Dr. Norazah Mohd Suki is currently an Associate Professor at the Labuan School of International Business \& Finance, Universiti Malaysia Sabah, Labuan International Campus. She has supervised several postgraduate students at MBA and PhD level. Her research interests include Electronic Marketing, E-Commerce, MCommerce, Consumer Behaviour, Mobile Learning and areas related to Marketing.

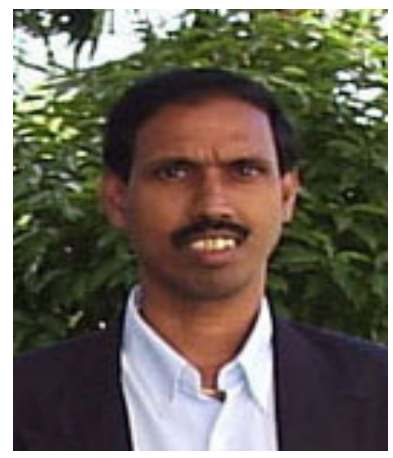

Assoc. Prof. T. Ramayah is an Associate Professor at the School of Management in USM. He teaches mainly courses in Research Methodology and Business Statistics and has also conducted training courses for the local government (Research Methods for candidates departing overseas for higher degree, Jabatan Perkhidmatan Awam). 